Special Issue/Collection: Research Project PRIN-MIUR 2015

"The forest-wood value chain: biomass supply, traceability, C-footprint. Innovation for bioarchitecture and energy efficiency"

Guest Editors: Scarascia Mugnozza G, Maesano M, Romagnoli M

\title{
Thermo-modified native black poplar (Populus nigra L.) wood as an insulation material
}

\author{
Luigi Todaro (1), \\ Stefania Liuzzi ${ }^{(2)}$, \\ Antonio Marco Pantaleo (3), \\ Valentina Lo Giudice ${ }^{(1)}$, \\ Nicola Moretti ${ }^{(1)}$, \\ Pietro Stefanizzi ${ }^{(2)}$
}

\begin{abstract}
Extensive research projects have been carried out on thermal modification of wood material, yet thermal properties of thermally modified poplar wood have not been comprehensively investigated. Black poplar (Populus nigra L.) is a Eurasian species native to Italy which is rarely used for the production of highperformance products, though it is one of the least expensive hardwoods on the market. To explore alternative applications of poplar wood such as building facade or fire resistance materials, reliable data of thermal behaviour of thermally modified wood at high temperatures are needed. In this work, the thermal behaviour of native black poplar wood after thermal modification at different temperatures $\left(180{ }^{\circ} \mathrm{C}, 200{ }^{\circ} \mathrm{C}\right.$ and $\left.220^{\circ} \mathrm{C}\right)$ was analyzed. Thermal conductivity, thermal diffusivity and porosity were measured on poplar wood boards, as well as mass loss and wood color changes after heat treatment were quantified. Thermal conductivity of wood samples showed significant changes after treatment at 200 and $220{ }^{\circ} \mathrm{C}$, but not at $180{ }^{\circ} \mathrm{C}$. Wood porosity showed significant differences with the control when the samples were modified at a temperature of $220{ }^{\circ} \mathrm{C}$. Increasing color differences were observed in wood samples by increasing the thermal modification temperature. Also, the mass loss of wood samples increased and equilibrium moisture content significantly dropped down after thermal modification. Our results showed that the use of thermally-modified black poplar wood could be considered as a viable alternative to chemically treated wood products for specific applications where high insulation is needed, such as saunas or windows, and for façades elements.
\end{abstract}

\section{Keywords: Thermal Modification, Poplar, Insulation, Thermal Properties}

used in industrial wood processing. This makes poplar one of the most promising wood resources in the next future. Despite the cultivated area, Italian native poplar is currently used only for niche products; however, investigations are ongoing to develop new applications with higher quality and market value. Indeed, the main drawback of poplar wood is its durability, which is lower compared to the dominant commercial hardwood species, such as Chestnut and European oak, and this has ham-
(1) School of Agricultural, Forest, Food and Environmental Science (SAFE) -University of Basilicata, Potenza (Italy); (2) Department of Civil Engineering Sciences and Architecture Polytechnic University of Bari, Bari (Italy); (3) Department of Agro-Environmental Sciences University of Bari (Italy)

@ Valentina Lo Giudice (valentina.logiudice@unibas.it)

Received: Nov 30, 2020 - Accepted: Apr 08, 2021

Citation: Todaro L, Liuzzi S, Pantaleo AM, Lo Giudice V, Moretti N, Stefanizzi P (2021). Thermo-modified native black poplar (Populus nigra L.) wood as an insulation material. iForest 14: 268-273. - doi: 10.3832/ifor3710-014 [online 2021-05-29]

Communicated by: Giacomo Goli pered its industrial transformation in high performance products.

Current research efforts aimed at adding values to final poplar wood products are focused on processing techniques and wood modification processes. Among these, thermal modification of wood provide broadly recognized benefits, such as improved dimensional stability, uniform coloration and higher biological resistance. However, the lack of technical standards for the material properties and technological processes still represent a bottleneck to this aim, as limited knowledge is currently available on the defects of thermally modified wood, such as reduced mechanical properties, elevated internal tensions, checking and splitting (Zawadzki et al. 2016).

Black poplar (Populus nigra L.) is a fastgrowing, deciduous tree species belonging to Salicaceae family (Praciak 2013) which can be found in floodplain forests (De Rigo et al. 2016) throughout Europe, northern Africa, central and western Asia (Fig. S1 in Supplementary material). Its wood has many technological qualities; although not particularly strong, poplar wood is relatively fire-resistant and shockproof, and 
has a soft, fine texture. Traditionally, it was used for clogs, carts, furniture and also flooring near to open fireplaces (Cottrell 2004). Nowadays, it is used for pulp and paper, and its fast growth rate makes it a suitable bioenergy crop (Guerra et al. 2013). Moreover, poplar extracts have antioxidant and anti-inflammatory effects (Jerković \& Mastelić 2003, Todaro et al. 2017).

The establishment of multipurpose tree plantations is currently increasing throughout Europe, due to the increasing demand for natural products, ecosystem services and sustainability issues. Consequently, there is a strong interest in physical, mechanical and chemical characterization of modified wood and its by-products, aimed to generate diversified, innovative and renewable products using on site bio-resources such as wood.

Heat treatment of wood is an economically competitive process that has its stable market position in Europe due to its low environmental impact and technical advantages in extending wood products lifetime (Ditommaso et al. 2020). In the last decade, technical advantages and disadvantages of thermal wood modification (TMT) have been widely investigated. According to Ferrari et al. (2013), this process involves treating wood at high temperature up to $260^{\circ} \mathrm{C}$ in oxygen-free environment to avoid combustion. Thermal modification is nowadays widely employed to increase the durability of wood or to modify the physical, mechanical, or aesthetic properties of sawn timber, veneer or particles used in the production of wood composites. The main drawback of this process is the reduction of mechanical performances of thermally modified wood. Thermal modification is, therefore, often proposed as a means for valorizing wood of species with low natural durability (Boruvka et al. 2018) or for new applications of timber and related materials which have few market outlets (Todaro et al. 2015, Sandak et al. 2016). Recently, Sandberg et al. (2017), reviewed the available methods for improving wood technological properties of several tree species. Rousset et al. (2004) determined the mass transfer properties in the hygroscopic range before and after $200{ }^{\circ} \mathrm{C}$ treatment in wood samples from Populus $x$ canadensis $\mathrm{cv}$. robusta to define the usage of thermally modified products in the packaging sector, due to the influence of mass transfer properties on the gas and water vapour transfer capabilities. Goli et al. (2014) investigated the effect of heat treatment on some physical and mechanical properties of poplar wood (Populus alba L.). The initial condition of the treated material (wet or dry) and the dry mass loss (7 to $10 \%$ ) caused very different effects on the Modulus of Elasticity (MOE), as heat treatments applied on wet wood material resulted in a lower reduction of MOE when compared to the same treatments applied on oven-dry material. Kozakiewicz et al. (2020) studied the effects of thermal process conditions on the chemical composition and mechanical properties of black poplar wood, finding that its surface properties were significantly altered by heat, thus affecting the technological applications of wood. Salca \& Hiziroglu (2014) reported that heat modification has a negative effect on the hardness characteristics of different wood species (including yellow poplar), while their surface quality improved. Chu et al. (2016) studied the surface characteristics of poplar wood subjected to high temperature and concluded that the wettability of treated wood decreased, while the surface brittleness increased after treatment. Korkut et al. (2013) found that wood thermal modification improves the dimensional stability and some other important wood properties such as thermal conductivity. Changes caused by heat modification on thermal conductivity and density of Pannonian poplar (Populus $\times$ euramericana cv. Pannónia) and spruce (Picea abies Karst.) were assessed by Sandak et al. (2016). The authors found that the variation of the thermal conductivity was greater than the variation of density in both wood species. Using the same temperature treatment $\left(180^{\circ} \mathrm{C}\right)$, Pásztory et al. (2017) reported of a reduction in both den-

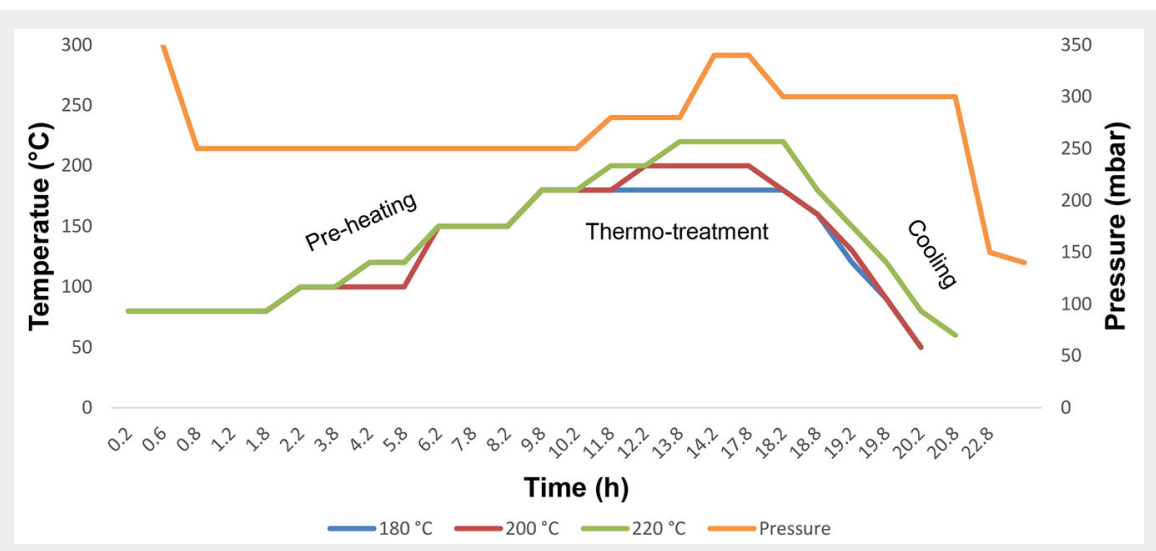

Fig. 1 - Thermal modification parameters used during the heat treatment of black poplar wood samples. sity and thermal conductivity of wood which was dependent on treatment duration. The influence of the duration of heat modifications on thermal conductivity properties of rubber wood was also investigated by Srivaro et al. (2019). The thermal conductivity of rubber wood samples after long heating treatment resulted similar to typical insulation materials, such as fiberglass, rockwool and extruded polystyrene.

The objective of this study was to analyze the effect of different heat modification temperatures $\left(180,200\right.$ and $220^{\circ} \mathrm{C}$ ) on thermal, physical and mechanical properties (mass loss, color changes, and MOE) of native black poplar wood.

\section{Materials and methods}

Boards of black poplar wood (size: $200 \times$ $20 \times 3 \mathrm{~cm}$, width $\times$ length $\times$ thickness) from 8 different trees grown in the high forest of Calvello (Basilicata Region, Southern Italy) were randomly selected. Each board was cut in plain-sawn.

\section{Thermo vacuum modification}

A thermal modification process in a pressvacuum plant developed by WDE Maspell s.r.I. (Terni, Italy) has been adopted. Black poplar wood boards were subjected to thermal modification at $180{ }^{\circ} \mathrm{C}, 200{ }^{\circ} \mathrm{C}$ and $220{ }^{\circ} \mathrm{C}$ for 3 hours at the Laboratory of Wood Technology, University of Basilicata, Italy. Boards were firstly dried for $4 \mathrm{~h}$ in vacuum conditions (185-200 mbar) at a temperature of $90{ }^{\circ} \mathrm{C}$ (Fig. 1). The thermal process was applied on the dried samples by gradually increase the temperature to the final temperature in about $15 \mathrm{~h}$. More details regarding the Thermo-Vacuum process and its technical parameters are reported by Allegretti et al. (2012) and Sandak et al. (2015).

\section{Thermal conductivity and thermal diffusivity}

From the mentioned thermally modified boards, a total of 24 samples without defects ( 6 for each of the 3 thermal treatments, and 6 for control) were randomly selected and then cut to obtain specimens of size $17 \times 17 \times 2 \mathrm{~cm}(\mathrm{w} \times 1 \times \mathrm{t}-$ Fig. 2$)$. A series of 3 measurements were performed on each of the 24 specimens for a total of 72 measurements. Thermal conductivity and diffusivity of specimens have been measured at $25^{\circ} \mathrm{C}$ in the radial direction using a thermal properties analyzer ISOMET 2104 (Applied Precision Ltd., Bratislava, Slovakia - Fig. 2). The evaluation was based on the analysis of the temperature response of the analyzed material to heat flow impulses (Bekhta \& Dobrowolska 2006).

\section{Colour variation and mass loss}

Wood color modifications after heat treatment were recorded by measuring the three coordinates $L^{*}, a^{*}$ and $b^{*}$, according to the CIELAB system. The $L^{*}$ coordinate is the lightness, ranging from o (black) to 100 (white); $a^{*}$ refers to the position of speci- 
mens in the color space between red/magenta (positive values) and green (negative values); $b^{*}$ indicates the specimen position in the color space between yellow (positive values) and blue (negative values). A Minolta CM-2002 Spectrophotometer (Minolta Corp., Osaka, Japan) was used with a pulsed Xenon arc light source. The total color variation was determined as follows (eqn. 1):

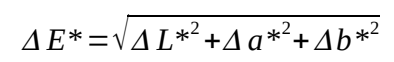

The color measurements have been determined on a total of 16 boards, 4 for each of the thermal modification processes, and 4 for control. In particular, for each boards, 3 measurement areas with a diameter of 8 $\mathrm{mm}$ were assessed, for a total of 48 measurement areas. Their average value was then calculated and statistically analysed.

Mass loss (ML) after heat treatment was evaluated with 3 measurements on each of 12 boards, 3 for each of the thermal modification processes, and 3 for control, according to the formula (eqn. 2):

$$
M L(\%)=\frac{m_{\text {PreTMT }}-m_{\text {postTMT }}}{m_{\text {preTMT }}} \cdot 100
$$

where $m_{\text {рreтмт }}$ is the initial oven-dried mass of wood sample and $m_{\text {postmm }}$ is the ovendried mass of the same sample after thermal modification.

\section{Porosity and moisture content}

An Ultrapyc ${ }^{\circledast}$ 1200e pycnometer (Quantachrome Instruments Corp., Boynton Beach, FL, USA) was used to measure the porosity on 12 specimens, 3 for each of the heat treatments, and 3 for control, with dimensions of $2 \times 2 \times 1 \mathrm{~cm}(\mathrm{w} \times \mathrm{I} \times \mathrm{t})$, in terms of percentage of pore space within the sample. The moisture content (\%) was calculated as the difference between the weight of the specimens after drying at 105 ${ }^{\circ} \mathrm{C}$ for 24 hours and the weight recorded at environmental conditions $\left(T=20^{\circ} \mathrm{C}, \mathrm{RH}=\right.$ $50 \%$. Density was also evaluated at environmental conditions on the same 12 non-standard wood specimens.

\section{Modulus of elasticity}

The modulus of elasticity (MOE, $\mathrm{N} \mathrm{mm}^{-2}-$ also known as Young's Modulus) was calculated for 72 boards equally distributed between modified and unmodified material. For each board 4 measurements of MOE were taken, for a total of 288 recorded values. MOE measures the stiffness of a material based on the relationship between stress (force per unit area) and strain (proportional deformation). The stress is proportional to strain within the elastic limit of the material according to Hooke's law. The dynamic MOE was calculated by the Christoffel's equation (eqn. 3):

$$
M O E=\rho \cdot V^{2}
$$

where $\rho$ is the density of the specimen at a given moisture content $\left(\mathrm{kg} \mathrm{m}^{-3}\right)$, and $V$ is

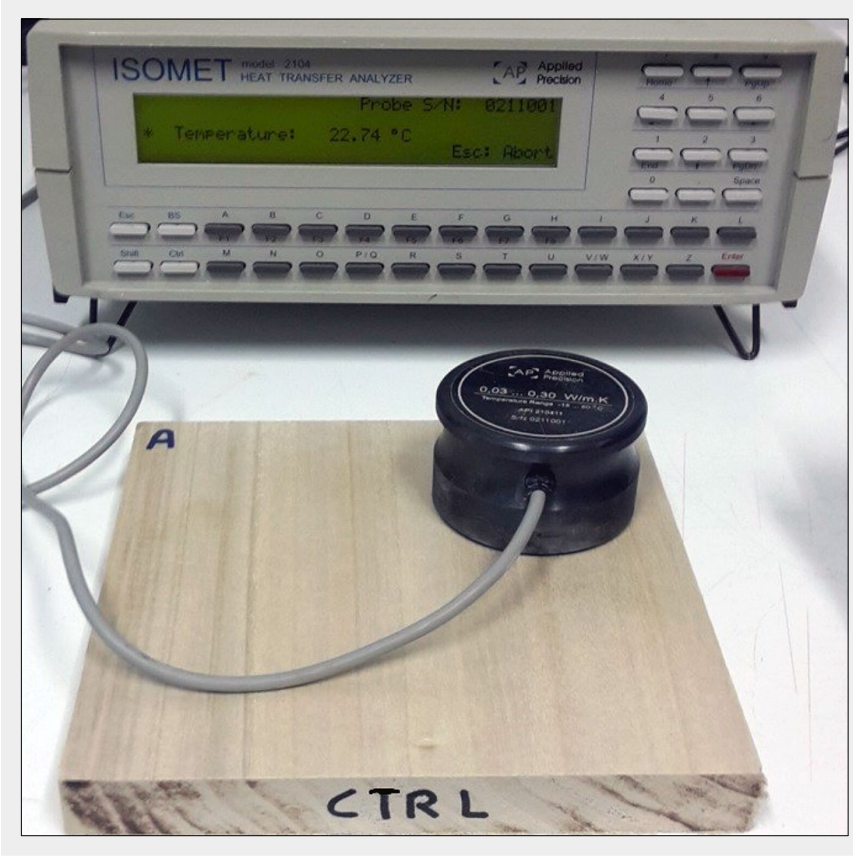

Fig. 2 - Set up of the measurement of thermal properties in three different points on each wood surface. the velocity of sound propagation $\left(\mathrm{m} \mathrm{s}^{-1}\right)$. The MOE was measured using a Microsecond Timer (Fakopp Enterprise, Agfalva, Hungary), with a resonance frequency of $23 \mathrm{kHz}$. This device measures the stress wave velocity of wood samples in the fiber direction through a transducer pin placed at a distance of $1 \mathrm{~m}$ with an angle of $45^{\circ}$. The signal was generated by a hammer tap on the start sensor and the device measures the propagation time. By knowing the distance between the two sensors, the wave velocity was calculated. Each measurement lasted less than 1 minute with a time measurement error of \pm 3 microseconds.

\section{Statistical analysis}

Differences between untreated and thermo-modified poplar wood samples in terms of thermal properties, color variation, mass loss, modulus of elasticity were tested by Analysis of variance (ANOVA) and the related Duncan's mean separation test (Duncan 1955) using the software Excel $2007^{\circledR}$ (Microsoft, Redmond, WA, USA).

\section{Results and discussion}

\section{Thermal and physical properties}

The measurement probe was located in three different points of the larger face of each specimen. The average value and the standard deviation for each material was then calculated (Tab. 1). Based on the results, the thermal conductivity decreases with the heat temperature, while the thermal diffusivity has an opposite trend. Previous studies showed that the thermal conductivity values decrease as the temperature increases, and the rate of decrease strongly depends on the temperature of the thermal modification (Kol \& Sefil 2011, Olarescu et al. 2015, Pásztory et al. 2017). This implies that, in terms of insulation, thermo-modified wood would perform better than unmodified wood. The thermal wood properties are linked to the coefficient $\alpha$, which represents the ratio between the coefficient of thermal conductivity $(K)$ and the product of specific heat capacity (c) and density ( $\rho$ - eqn. 4$)$ :

$$
\alpha=\frac{K}{c \cdot \rho}
$$

where $\rho$ multiplied by $c$ represents the volumetric heat capacity. The coefficient $\alpha$ could be used for testing the efficiency of the wood heating process for industrial purposes (Radmanović et al. 2014). It reflects how long the heating or cooling process will take under a given supply. The thermal diffusivity, which is the component of the thermal conductivity equation, pro-
Tab. 1 - Mean values \pm standard deviation of thermal properties of black poplar wood subjected to different heat treatment. Different letters in columns indicate significant $(p<0.05)$ differences between means after Duncan test.

\begin{tabular}{cccc}
\hline Treatment & $\begin{array}{c}\text { Thermal } \\
\text { conductivity } \\
\left(\mathrm{W} \mathrm{m} \mathrm{m}^{-1} \mathrm{~K}^{-1}\right)\end{array}$ & $\begin{array}{c}\text { Volumetric } \\
\text { heat capacity } \\
\left(\times 10^{6} \mathrm{~J} \mathrm{~m}^{-3} \mathrm{~K}^{-1}\right)\end{array}$ & $\begin{array}{c}\text { Thermal } \\
\text { diffusivity } \\
\left(\times 10^{-6} \mathrm{~m}^{2} \mathrm{~s}^{-1}\right)\end{array}$ \\
\hline $220^{\circ} \mathrm{C}$ & $0.100 \pm 0.008^{\mathrm{a}}$ & $0.530 \pm 0.052^{\mathrm{a}}$ & $0.189 \pm 0.006^{\mathrm{a}}$ \\
$200^{\circ} \mathrm{C}$ & $0.111 \pm 0.007^{\mathrm{b}}$ & $0.593 \pm 0.044^{\mathrm{b}}$ & $0.188 \pm 0.009^{\mathrm{a}}$ \\
\hline $180{ }^{\circ} \mathrm{C}$ & $0.118 \pm 0.004^{\mathrm{bc}}$ & $0.682 \pm 0.034^{\mathrm{c}}$ & $0.173 \pm 0.006^{\mathrm{b}}$ \\
\hline Control & $0.124 \pm 0.004^{\mathrm{c}}$ & $0.723 \pm 0.033^{\mathrm{d}}$ & $0.172 \pm 0.004^{\mathrm{b}}$ \\
\hline
\end{tabular}




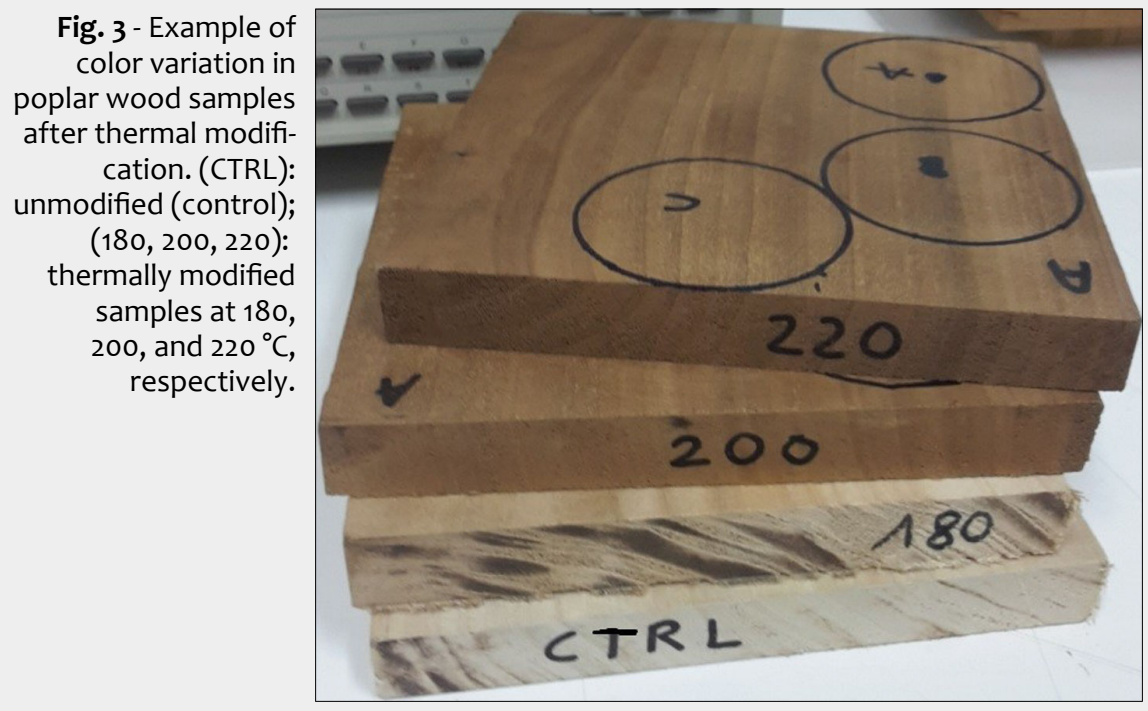

Tab. 2 - Mean values \pm standard deviation of density, porosity and moisture content. Different letters in columns indicate significant $(p<0.05)$ differences between means after Duncan test.

\begin{tabular}{cccc}
\hline Treatment & $\begin{array}{c}\text { Density } \\
\left(\mathbf{k g ~ m}^{-3}\right)\end{array}$ & $\begin{array}{c}\text { Porosity } \\
\mathbf{( \% )}\end{array}$ & $\begin{array}{c}\text { Moisture content } \\
\mathbf{( \% )}\end{array}$ \\
\hline $220^{\circ} \mathrm{C}$ & $401.5 \pm 11.8^{\mathrm{a}}$ & $53.3 \pm 0.4^{\mathrm{a}}$ & $5.0 \pm 0.5^{\mathrm{a}}$ \\
\hline $200^{\circ} \mathrm{C}$ & $407.6 \pm 19.9^{\mathrm{b}}$ & $59.1 \pm 1.7^{\mathrm{b}}$ & $5.2 \pm 0.5^{\mathrm{a}}$ \\
\hline $180^{\circ} \mathrm{C}$ & $406.8 \pm 9.2^{\mathrm{b}}$ & $59.1 \pm 1.8^{\mathrm{b}}$ & $7.3 \pm 0.6^{\mathrm{b}}$ \\
\hline Control & $441.3 \pm 10.0^{\mathrm{c}}$ & $61.3 \pm 1.4^{\mathrm{b}}$ & $9.9 \pm 0.9^{\mathrm{c}}$ \\
\hline
\end{tabular}

vides a measure of the heat transfer, i.e., the velocity of heat propagation in the wooden material. The lower its value, the longer the heat takes to pass through the material. Thus, the effectiveness of the insulation of a material depends on the thermal conductivity value as well as on the heat transfer velocity (Taoukil et al. 2013).

Tab. 2 reports the results of the physical properties of each set of specimens. The wood porosity dramatically drops when the temperature increases from 200 to 220 ${ }^{\circ} \mathrm{C}$. However, this trend is in contrast with the thermal conductivity trend. Indeed, the reduction in porosity for poplar wood modified at $220^{\circ} \mathrm{C}$ would predict an increase in density and thermal conductivity, which is in contrast with the results obtained. This could be due to changes in the wood chemical composition after thermal modification that could causes a degradation of the cell wall (Ling et al. 2016, Li et al. 2017). However, the effect of moisture content within the wood on its thermal conductivity could be more prominent than porosity. As reported by Zhou et al. (2013), the con-

Tab. 3 - Mean values \pm standard deviation of color coordinates in poplar wood. Different letters indicate significant $(p<0.05)$ differences between means after Duncan test.

\begin{tabular}{cccc}
\hline Treatment & $L^{*}$ & $a^{*}$ & $b^{*}$ \\
\hline $220^{\circ} \mathrm{C}$ & $42.14 \pm 3.09^{\mathrm{a}}$ & $7.91 \pm 1.58^{\mathrm{a}}$ & $19.91 \pm 3.71^{\mathrm{a}}$ \\
\hline $200^{\circ} \mathrm{C}$ & $46.76 \pm 2.91^{\mathrm{b}}$ & $8.05 \pm 0.49^{\mathrm{a}}$ & $21.84 \pm 1.84^{\mathrm{b}}$ \\
\hline $180^{\circ} \mathrm{C}$ & $57.94 \pm 5.41^{\mathrm{c}}$ & $7.42 \pm 1.04^{\mathrm{a}}$ & $27.17 \pm 2.88^{\mathrm{c}}$ \\
\hline Control & $72.36 \pm 1.84^{\mathrm{d}}$ & $2.95 \pm 0.43^{\mathrm{b}}$ & $22.01 \pm 0.73^{\mathrm{b}}$ \\
\hline
\end{tabular}

Tab. 4 - Mean values \pm standard deviation of mass loss and color parameters variation. Different letters in columns indicate significant $(p<0.05)$ differences between means after Duncan test.

\begin{tabular}{cccccc}
\hline Treatment & Mass loss & $\Delta L^{*}$ & $\Delta a^{*}$ & $\Delta b^{*}$ & $\Delta E^{*}$ \\
\hline $220^{\circ} \mathrm{C}$ & $9.67 \pm 0.57^{\mathrm{a}}$ & $32.09 \pm 7.08^{\mathrm{a}}$ & $-5.34 \pm 1.92^{\mathrm{a}}$ & $1.27 \pm 5.63^{\mathrm{a}}$ & $33.07 \pm 6.97^{\mathrm{a}}$ \\
$200^{\circ} \mathrm{C}$ & $7.88 \pm 0.77^{\mathrm{a}}$ & $23.80 \pm 2.36^{\mathrm{b}}$ & $-5.19 \pm 0.60^{\mathrm{b}}$ & $0.55 \pm 3.34^{\mathrm{b}}$ & $24.55 \pm 2.54^{\mathrm{b}}$ \\
\hline $180^{\circ} \mathrm{C}$ & $4.40 \pm 0.20^{\mathrm{b}}$ & $14.38 \pm 3.64^{\mathrm{c}}$ & $-4.01 \pm 1.50^{\mathrm{a}}$ & $-4.69 \pm 2.96^{\mathrm{b}}$ & $15.76 \pm 4.51^{\mathrm{c}}$ \\
\hline Control & - & - & - & - & - \\
\hline
\end{tabular}

ductivity increased almost linearly with moisture content at a given temperature, which is explained by the conduction properties of the water.

\section{Color variation and mass loss}

Wood color variation represents one of the most significant changes associated with thermal modification (Fig. 3). Wood darkens under the influence of heat (Srinivas \& Pandey 2012). According to Patzelt et al. (2003), color changes are strongly correlated with mass loss, while Bekhta \& Niemz (2003) stated that color variations could be used to predict the mechanical alterations of modified wood. Sundqvist (2009) reported that an increase in temperature during modification produces a decrease in lightness. Tab. 3 shows a dramatic variation of $L^{*}$ in black poplar wood after thermal modification at $220^{\circ} \mathrm{C}$, reaching a very low value $\left(L^{*}=42.14 \pm 3.09\right)$ as compared to control sample $\left(L^{*}=72.36 \pm 1.84\right)$. The $a^{*}$ value increased significantly after thermal modification in all cases, while black poplar wood modified at a temperature of $180{ }^{\circ} \mathrm{C}$ showed a higher $b^{*}$ value $(27.17 \pm 2.88)$ compared to unmodified specimens (22.01 \pm 0.73), thermally modified specimens heated at $200{ }^{\circ} \mathrm{C}(21.84 \pm 1.84)$ and those heated at $220{ }^{\circ} \mathrm{C}(19.91 \pm 3.71)$. Thus, thermal modification caused an extensive darkening of wood (strong reduction of $L^{*}$ ), a reddening (increase of $a^{*}$ value) and a weakly yellowing (increase of $b^{*}$ value).

Black poplar wood after heat treatment showed a mass loss of $4.4 \%, 7.8 \%$ and $9.6 \%$ at 180,200 and $220{ }^{\circ} \mathrm{C}$, respectively, compared with control wood. This confirms previous evidences on mass loss after heat treatment due to changes in chemical composition of wood, which are strongly dependent on temperature (Esteves \& Pereira 2009). Moreover, we found that color difference increased as heating temperature increased: mean $\Delta E^{*}$ value was 15.8 , 24.6 and 33.1 for treatments at 180, 200, and $220^{\circ} \mathrm{C}$, respectively (Tab. 4).

\section{Modulus of elasticity}

The modulus of elasticity (MOE) of poplar wood specimens was significantly higher for wood samples modified at $180^{\circ} \mathrm{C}$ than for those heated at $220{ }^{\circ} \mathrm{C}$. Compared to control (10,392 N mm-2), MOE increased to $11,509 \mathrm{~N} \mathrm{~mm}^{-2}$ at $180^{\circ} \mathrm{C}^{\circ}$ and then decreased to $9,778 \mathrm{~N} \mathrm{~mm}^{-2}$ at $220^{\circ} \mathrm{C}$. Based on these results, MOE seems to increase after milder heat modification of wood, while it decreases with strong modification temperatures (Tab. 5). Hill (2006) reported a slight increase in MOE when the wood is thermally modified for a short period time. Kubojima et al. (1998) reported an increase of the MOE of Picea sitchensis Carr. in the first 2 hours of treatment, followed by a constant value for wood treated at $120^{\circ} \mathrm{C}$ and $160{ }^{\circ} \mathrm{C}$. However, the reduction in wood strength after thermal modification is explained mainly by the degradation of wood structural components such as hemi- 
Tab. 5 - Mean values \pm standard deviation of Modulus of elasticity (MOE). Different letters indicate significant differences $(p<0.05)$ between means after Duncan test.

\begin{tabular}{cc}
\hline Treatment & MOE $\left(\mathrm{N} \mathrm{mm}^{-2}\right)$ \\
\hline $220{ }^{\circ} \mathrm{C}$ & $9,778.8 \pm 379.3^{\mathrm{a}}$ \\
\hline $200^{\circ} \mathrm{C}$ & $10,268.2 \pm 2562.4^{\mathrm{ab}}$ \\
\hline $180^{\circ} \mathrm{C}$ & $11,509.9 \pm 1633.7^{\mathrm{b}}$ \\
\hline Control & $10,392.6 \pm 703.7^{\mathrm{ab}}$ \\
\hline
\end{tabular}

celluloses, cellulose and lignin. Fengel \& Wegener (1989) showed the degradation of hemicelluloses at low temperature because of their low molecular weight. Burmester (1975) reports that the thermal modification of wood results in a strong reduction of the hemicellulose content. Thus, high temperature treatments promote chemical changes in the wood material which becomes more fragile, due to the decomposition of polymers which consequently leads to a decrease in elasticity.

\section{Conclusions}

Thermal modification processes at different temperatures have been applied to native black poplar wood with the aim of assessing their influence on some important properties of wood for non-structural applications. One of the main concerns of wood thermal modification is the decrease in mechanical strength; therefore, thermally modified wood cannot be used for structural applications so far. According to our results, mean MOE values of sample wood slightly increased after heat treatment at $180{ }^{\circ} \mathrm{C}$ compared to control samples, though it substantially decreases when the temperature increased.

Black poplar wood showed an increase of mass loss with increasing heat modification temperature. The thermal modification treatment affects the chemical structure of wood and consequently its color. However the thermal modification had a considerable effect on the thermal conductivity of poplar wood samples, which decreased with increasing the treatment temperature.

Black poplar wood may have some potential in the future if thermally treated wood could be used in the structural application, also considering its interesting workability. The low thermal conductivity value, along with the low cost of production and processing, make this wood a promising material for the thermal insulation of the building envelope.

\section{Acknowledgments}

We thank Dr. D. Franco for taking part in the thermal analysis of the wood samples.

\section{References}

Allegretti O, Brunetti M, Cuccui I, Ferrari S, Nocetti M, Terziev N (2012). Thermo-vacuum modi- fication of spruce (Picea abies Karst.) and fir (Abies alba Mill.) wood. BioResources 7: 36563669. [online] URL: http://ojs.cnr.ncsu.edu/ind ex.php/BioRes/article/view/BioRes_07_3_3656_ Allegretti Thermo Vacuum Spruce Fir

Bekhta P, Niemz P (2003). Effect of high temperature on the change in color, dimensional stability and mechanical properties of spruce wood. Holzforschung 57: 539-546. - doi: 10.1515/ HF.2003.080

Bekhta P, Dobrowolska E (2006). Thermal properties of wood-gypsum boards. Holzalsroh-und werkstoff 64: 427-428. - doi: 10.1007/s00107-00 5-0074-8

Boruvka V, Zeidler A, Holeček T, Dudík R (2018). Elastic and strength properties of heat-treated beech and birch wood. Forests 9: 197. - doi: $10.3390 /$ f9040197

Burmester A (1975). Zur dimensions stabilisierung von Holz [For the dimensional stabilization of wood]. Holz als Roh- und Werkstoff 33 (9): 333-335. [in German] - doi: 10.1007/BF02612789 Chu D, Xue L, Zhang Y, Kang L, Mu J (2016). Surface characteristics of poplar wood with hightemperature heat treatment: wettability and surface brittleness. BioResources 11: 69486967. - doi: 10.15376/biores.11.3.6948-6967

Cottrell J (2004). Conservation of black poplar (Populus nigra L.). Information Note 57, Forestry Commission, Edinburgh, UK.

De Rigo D, Enescu CM, Houston Durrant T, Caudullo G (2016). Populus nigra in Europe: distribution, habitat, usage and threats. In: "European Atlas of Forest Tree Species”. EU Publication Office, Luxembourg, pp. e0182a4. [online] URL: http://www.researchgate.net/publication/ 299470695

Ditommaso G, Gaff M, Kacík F, Sikora A, Sethy A, Corleto R, Razaei F, Kaplan L, Kubs J, Das S, Kamboj G, Gasparík M, Sedivka P, Hysek S, Macku J, Sedlecky M (2020). Interaction of technical and technological factors on qualitative and energy/ecological/economic indicators in the production and processing of thermally modified merbau wood. Journal of Cleaner Production 252: 119793. - doi: 10.1016/j.jclepro.2019. 119793

Duncan DB (1955). Multiple range and multiple F tests. Biometrics 11: 1-42. - doi: 10.2307/3001478 Esteves B, Pereira H (2009). Wood modification by heat treatment: a review. BioResources 4 (1): 370-404.

Fengel D, Wegener G (1989). Wood: chemistry, ultrastructure, reactions. Walter de Gruyter, New York, USA, pp. 626. [online] URL: https:// books.google. com/books?id=x1B4uITKntoC

Ferrari S, Allegretti O, Cuccui I, Moretti N, Marra $M$, Todaro $L$ (2013). A revaluation of Turkey oak wood (Quercus cerris L.) through combined steaming and thermo-vacuum treatments. BioResources 8: 5051-5066. [online] URL: http://ojs.cnr.ncsu.edu/index.php/BioRes/article /view/4197

Goli G, Marcon B, Fioravanti M (2014). Poplar wood heat treatment: effect of air ventilation rate and initial moisture content on reaction kinetics, physical and mechanical properties. Wood Science and Technology 48: 1303-1316. doi: 10.1007/s00226-014-0677-5

Guerra FP, Wegrzyn JL, Sykes R, Davis MF, Stanton BJ, Neale DB (2013). Association genetics of chemical wood properties in black poplar ( $P$ opulus nigra). New Phytologist 197: 162-176. - doi: 10.1111/nph.12003

Hill (2006). Wood modification: chemical, thermal and other processes. John Wiley and Sons, Chichester, UK, vol. 5, pp. 260.

Jerković I, Mastelić J (2003). Volatile compounds from leaf-buds of Populus nigra L. (Salicaceae). Phytochemistry 63: 109-113. - doi: 10.1016/So0319422(02)00706-9

Kol HS, Sefil Y (2011). The thermal conductivity of fir and beech wood heat treated at 170, 180, 190, 200, and $212{ }^{\circ} \mathrm{C}$. Journal of Applied Polymer Science 121: 2473-2480. - doi: 10.1002/app.33885 Korkut S, Aytin A, Tasdemír C, Gurau L (2013). The transverse thermal conductivity coefficients of wild cherry wood heat-treated using the ThermoWood method. In: Proceedings of the " $10^{\text {th }}$ International Conference on Wood Science and Engineering in the $3^{\text {rd }}$ Millennium" (Campean M ed). Brasov (Romania) 5-7 Nov 2015. PRO Ligno, Brasov, Romania, pp. 679-683. Kozakiewicz P, Drozdzek $M$, Laskowska $A$, Grzeskiewicz M, Bytner O, Radomski A, Mróz A, Betlej I, Zawadzki J (2020). Chemical composition as factor affecting the mechanical properties of thermally modified black poplar (Populus nigra L.). BioResources 15: 3915-3929. - doi: 10.15376/biores.15.2.3915-3929

Kubojima Y, Okano T, Ohta M (1998). Vibrational properties of Sitka spruce heat-treated in nitrogen gas. Journal of Wood Science 44 (1): 73-77. doi: $10.1007 /$ BFo0521878

Li T, Cheng D, Avramidis S, Walinder MEP, Zhou $D$ (2017). Response of hygroscopicity to heat treatment and its relation to durability of thermally modified wood. Construction and Building Materials 144: 671-676. - doi: 10.1016/j.con buildmat.2017.03.218

Ling Z, Ji Z, Ding D, Cao J, Xu F (2016). Microstructural and topochemical characterization of thermally modified poplar (Populus cathayana) cell wall. BioResources 11: 786-799. - doi: 10.15376/biores.11.1.786-799

MIPAAFT (2019). RAF Italia 2017-2018. Rapporto sullo stato delle foreste e del settore forestale in Italia [Report on the state of forests and on the forest sector in Italy]. Compagnia delle Foreste, Arezzo, Italy, pp. 284. [in Italian]

Olarescu CM, Campean M, Cosereanu C (2015). Thermal conductivity of solid wood panels made from heat-treated spruce and lime wood strips. In: Proceedings of the " $10^{\text {th }}$ International Conference on Wood Science and Engineering in the Third Millennium" (Campean M ed). Brasov (Romania) 5-7 Nov 2015. PRO Ligno, Brasov, Romania, pp. 377-382.

Pásztory Z, Horváth N, Börcsök Z (2017). Effect of heat treatment duration on the thermal conductivity of spruce and poplar wood. European Journal of Wood and Wood Products 75: 843845. - doi: 10.1007/s00107-017-1170-2

Patzelt M, Emsenhuber G, Stingl R (2003). Colour measurement as means of quality control of thermally treated wood. In: Proceedings of the $1^{\text {st }}$ "European Conference on Wood Modification”. Gent (Belgium) 3-4 Apr 2003, pp. 213-218. Praciak A (2013). The CABI encyclopedia of forest trees. CABI, Oxfordshire, UK, pp. 536.

Radmanović K, Dukić I, Pervan S (2014). Specifični toplinski kapacitet drva [Specific heat ca- 
pacity of wood]. Drvna industrija: Znanstveni časopis za pitanja drvne tehnologije 65: 151-157. [in Croatian] - doi: 10.5552/drind.2014.1333

Rousset P, Perré P, Girard P (2004). Modification of mass transfer properties in poplar wood ( $P$. robusta) by a thermal treatment at high temperature. Holz als Roh-und Werkstoff 62: 113119. - doi: 10.1007/s00107-003-0459-5

Salca EA, Hiziroglu S (2014). Evaluation of hardness and surface quality of different wood species as function of heat treatment. Materials and Design 62: 416-423. - doi: 10.1016/j.mat des.2014.05.029

Sandak A, Sandak J, Allegretti O (2015). Quality control of vacuum thermally modified wood with near infrared spectroscopy. Vacuum 114: 44-48. - doi: 10.1016/j.vacuum.2014.12.027 Sandak A, Allegretti O, Cuccui I, Sandak J, Rosso L, Castro G, Negro F, Cremonini C, Zanuttini R (2016). Thermo-vacuum modification of poplar veneers and its quality control. BioResources 11: 10122-10139. - doi: 10.15376/biores.11.4.1012210139

Sandberg D, Kutnar A, Mantanis G (2017). Wood modification technologies - a review. iForest Biogeosciences and Forestry 10 (6): 895-908. doi: 10.3832 /ifor2380-010

Srinivas K, Pandey KK (2012). Photodegradation of thermally modified wood. Journal of Photochemistry and Photobiology B: Biology 117: 140145. - doi: 10.1016/j.jphotobiol.2012.09.013

Srivaro S, Börcsök Z, Pásztory Z (2019). Temperature dependence of thermal conductivity of heat-treated rubberwood. Wood Material Science and Engineering 16 (2): 81-84. - doi: 10.108 o/17480272.2019.1608298

Sundqvist B (2009). Pressure-temperature phase relations in complex hydrides. In: "Solid State Phenomena". Trans Tech Publications Ltd., vol. 150, pp. 175-195. - doi: 10.4028/www.scientific. net/SSP.150.175

Taoukil D, El bouardi A, Sick F, Mimet A, Ezbakhe $H$, Ajzoul T (2013). Moisture content influence on the thermal conductivity and diffusivity of wood-concrete composite. Construction and Building Materials 48: 104-115. - doi: 10.1016/j. conbuildmat.2013.06.067

Todaro L, Rita A, Negro F, Moretti N, Saracino A, Zanuttini R (2015). Behavior of pubescent oak (Quercus pubescens Willd.) wood to different thermal treatments. iForest - Biogeosciences and Forestry 8: 748-755. - doi: 10.3832/ifor1348007

Todaro L, Russo D, Cetera P, Milella L (2017). Effects of thermo-vacuum treatment on secondary metabolite content and antioxidant ac- tivity of poplar (Populus nigra L.) wood extracts. Industrial Crops and Products 109: 384390. - doi: 10.1016/j.indcrop.2017.08.052

Zawadzki J, Gawron J, Antczak A, Klosinska T, Radomski A (2016). The influence of heat treatment on the physico-chemical properties of pinewood (Pinus sylvestris L.). Drewno 59: 4957. - doi: 10.12841/wood.1644-3985.135.04

Zhou J, Zhou H, Hu C, Hu S (2013). Measurement of thermal and dielectric properties of medium density fiberboard with different moisture contents. BioResources 8: 4185-4192.

\section{Supplementary Material}

Fig. S1 - Map of the natural distribution of Populus nigra L.

Fig. S2 - Mean values and standard deviation of thermal conductivity.

Fig. S3 - Mean values and standard deviation of thermal diffusivity.

Fig. S4 - Mean values and standard deviation of porosity.

Link: Todaro_3710@supploo1.pdf 